\title{
PENGARUH KUALITAS KERJA DAN LINGKUNGAN KERJA TERHADAP KINERJA KARYAWAN PADA PT. ASAM JAWA
}

\author{
Siti Lam'ah Nasution \\ Dosen Fakultas Ekonomi dan Bisnis (FEB) Universitas Labuhanbatu \\ Email: sitinasution81@gmail.com
}

\begin{abstract}
Abstrak
Penelitian ini bertujuan untuk mengetahui Pengaruh Kualitas Kerja Dan Lingkungan Kerja Terhadap Kinerja Karyawan Pada PT. Asam Jawa. Jenis Penelitian Ini Adalah Penelitian Asosiatif. Pengumpulan Data Dalam Penelitian ini dilakukan melalui pendekatan survey dengan jenis penelitian deskriptif kuantitatif dengan menyebar kuesioner kepada 59 orang, sedangkan populasi yang dijadikan dalam penelitian ini adalah Karyawan PT. Asam Jawa. Teknik pengumpulan data dilakukan dengan wawancara, kuesioner dan studi dokumentasi. Alat analisis data yang digunakan pada penelitian ini menggunakan SPSS (Statistical Product Sofware Solution). Teknik analisis data dalam penelitian ini adalah analisis regresi linear berganda, pengujian hipotesis dengan menggunakan uji signifikan parsial (uji t), pengujian signifikan simultan (uji $F$ ), dan pengujian koefisien determinasi $\left(R^{2}\right)$. Hasil penelitian ini menunjukkan secara parsial (uji t) diketahui bahwa Kualitas Kerja $\left(X_{1}\right)$, berpengaruh signifikan terhadap Kinerja Karyawan pada PT. Asam Jawa. Kemudian Lingkungan Kerja $\left(X_{2}\right)$, berpengaruh signifikan terhadap Kinerja Karyawan pada PT. Asam Jawa. Pada pengujian secara simultan (uji $F$ ) diketahui Kualitas Kerja dan Lingkungan Kerja secara bersama-sama (secara serempak) berpengaruh positif dan signifikan terhadap Kinerja Karyawan PT. Asam Jawa dengan nilai $F_{\text {hitung }} 16,623>F_{\text {tabel }} 3,16$.
\end{abstract}

Kata Kunci: Kualitas Kerja, Lingkungan Kerja, Kinerja Karyawan.

\section{PENDAHULUAN}

\subsection{Latar Belakang Masalah}

Banyak usaha dan daya yang dilakukan untuk mengatasi, memenangkan serta mendapat manfaat dari perubahan itu sendiri. Salah satu hal yang ditekankan adalah komitmen setiap individu dalam organisasi untuk mengatasi perubahan. PT. Asam Jawa Kec. Torgamba sebagai sebuah perusahaan perkebunan parik kelapa sawit dan tidak luput dari perubahan dan persaingan sehingga menuntut setiap karyawannya untuk meningkatkan komitmen terhadap perusahaan PT. Asam Jawa.

PT. Asam Jawa adalah suatu perusahaan swasta yang bergerak dibidang perkebunan kelapa sawit dan industri pengolahan hasil perkebunan kelapa sawit yang menghasilkan minyak sawit yang dimiliki, Kelapa sawit merupakan salah satu tanaman perkebunan yang mempunyai peran penting bagi subsektor perkebunan. Pengembangan kelapa sawit antara lain memberi manfaat dalam peningkatan pendapatan petani dan masyarakat, produksi yang menjadi bahan baku industri pengolahan yang menciptakan nilai tambah di dalam negeri, ekspor CPO yang menghasilkan devisa dan menyediakan kesempatan kerja, dan hasil produksi ini kemudian dijual di pasar dalam negeri.Perkebunan milik PT. Asam jawa berlokasi di Torgamba yang sekaligus merupakan lokasi kegiatan produksi. Kantor pusat PT. Asam jawa yang berlokasi di Medan merupakan pusat pengendalian kegiatan oprasional perusahaan.

Kualitas merupakan konsep yang cukup sulit untuk dipahami dan disepakati. Dewasa ini kata kualitas mempunyai beragam interpretasi, tidak dapat didefinisikan secara tunggal, dan sangat tergantung pada konteksnya. Sumber daya manusia perlu dikembangkan secara terus 
menerus agar diperoleh kerja sumber daya manusia yang berkualitas dalam arti yang sebenarnya, yaitu pekerjaan yang dilaksanakannya akan menghasilkan sesuatu yang memang dikehendaki. Berkualitas bukan hanya pandai saja, tetapi memenuhi semua syarat kualitatif yang dituntut pekerjaan itu, sehingga pekerjaan itu benar-benar dapat diselesaikan sesuai rencana. Dengan perkataan lain kualitas kerja karyawan merupakan suatu standar persyaratan minimum yang harus dipenuhi agar seorang karayawan bisa menjalankan pekerjaannya dengan baik.

Lingkungan adalah segala sesuatu yang berada di luar perusahaan, tetapi mempunyai pengaruh atas pertumbuhan dan perkembangan perusahaan. Pada umumnya lingkungan tidak dapat dikuasai oleh perusahaan sehingga perusahaan harus menyesuaikan diri dengan lingkungannya. lingkungan kerja adalah keadaan di sekitar para pekerja sewaktu pekerja melakukan tugasnya yang mana keadaan ini mempunyai pengaruh bagi pekerja pada waktu melakukan pekerjaannya dalam rangka menjalankan operasi perusahaan. Lingkungan kerja mempunyai makna yang penting bagi pekerja dalam menyelesaikan tugasnya.

\section{TINJAUAN PUSTAKA}

\subsection{Kualitas Kerja}

Mangkunegara (2011) mendefenisikan kualitas kerja adalah ukuran seberapa baik seorang karyawan dalam mengerjakan apa yang seharusnya ia kerjakan. Dua hal yang dievaluasi dalam menilai kinerja karyawan berdasarkan definisi diatas yaitu perilaku dan kualitas kerja karyawan. Yang dimaksud dengan penilaian perilaku yaitu kesetiaan, kejujuran, kepemimpinan, kerjasama, loyalitas, dedikasi dan partisipasi karyawan. Sedangkan kualitas kerja adalah suatu standar fisik yang diukur karena hasil kerja yang dilakukan atau dilaksanakan karyawan atas tugas-tugasnya.

Siagian (2012) mengemukakan kualitas kerja merupakan upaya sistematis dalam kehidupan organisasional melalui cara dimana para karyawan diberi kesempatan untuk turut berperan menentukan cara mereka bekerja dan sumbangan yang mereka berikan kepada organisasi dalam rangka pencapaian tujuan dan berbagai sasarannya.

\subsection{Lingkungan Kerja}

Nitisemito (2011) mendefinisikan lingkungan kerja sebagai: "Segala sesuatu yang ada di sekitar para pekerja yang dapat mempengaruhi dirinya dalam menjalankan tugas-tugas yang diembankan". Menurut Sedarmayanti (2012) definisi lingkungan kerja sebagai berikut: Lingkungan kerja adalah keseluruhan alat perkakas dan bahan yang dihadapi, lingkungan sekitarnya di mana seseorang pekerja, metode kerjanya, serta pengaturan kerjanya baik sebagai perseorangan maupun sebagai kelompok.

\subsection{Kinerja Karyawan}

Pengertian kinerja karyawan menurut Hasibuan (2012) adalah "suatu hasil kerja yang dicapai seseorang dalam melaksanakan tugas-tugas yang dibebankan kepadanya didasarkan atas kecakapan, pengalaman, dan kesungguhan serta waktu". Karyawan yang mempunyai sifatsifat dorongan yang melatar belakangi dan melakukan pekerjaan dengan lebih baik. Tentu hal ini bertitik tolak pada pemenuhan kebutuhan yang dilakukan karyawan.

Menurut Mangkunegara (2011) menyatakan bahwa' kinerja adalah hasil kerja secara kualitas dan kuantitas yang dicapai oleh seorang pegawai dalam melaksanakan tugasnya sesuai dengan tanggung jawab yang diberikan kepadanya.

\subsection{Kerangka Konseptual}

Kerangka konseptual dari penelitian ini adalah: 


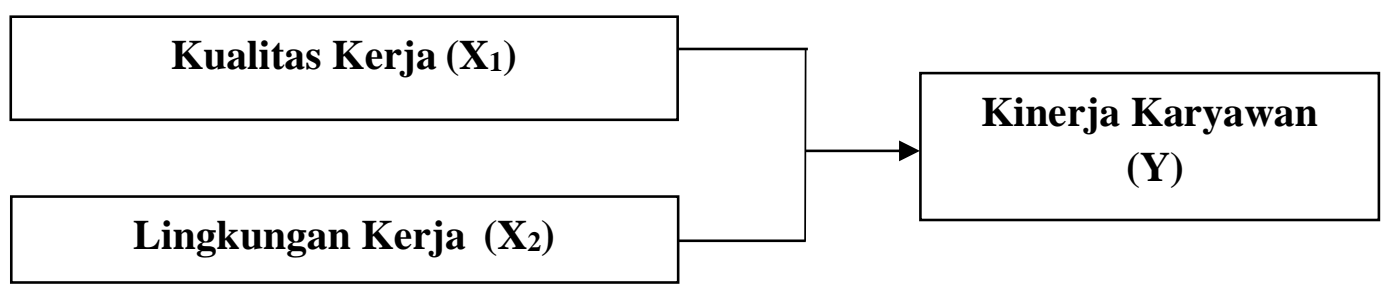

\section{Gambar 2.1. Kerangka Konseptual}

\section{METODE PENELITIAN}

\subsection{Jenis Penelitian}

Jenis penelitian yang digunakan dalam penelitian ini adalah penelitian assosiatif, yakni penelitian yang menghubungkan antara dua variabel atau lebih Sugiyono (2010). Dengan hubungan kausal yaitu hubungan yang bersifat sebab akibat Sugiyono (2010). Tempat dan waktu penelitian ini dilakukan pada PT. Asam Jawa yang berada di Kecamatan Torgamba Kabupaten Labuhan Batu Selatan.

\subsection{Batasan Operasional}

Batasan operasional variabel digunakan untuk menghindari kesimpangsiuran dalam membahas dan menganalisa permasalahan dalam penelitian ini. Oleh karena itu, dibuat suatu batasan operasional antara lain:

1. Variabel bebas (Independent Variable) terdiri dari:

Kualitas Kerja $\left(\mathrm{X}_{1}\right)$, Lingkungan Kerja $\left(\mathrm{X}_{2}\right)$.

2. Variabel terikat (Dependent Variable) terdiri dari:

Kinerja Karyawan (Y).

\subsection{Populasi dan Sampel}

Populasi yang diambil dalam penelitian ini adalah menggunakan teknik pengambilan sampel menggunakan sensus dan mengambil sampel dari seluruh populasi (sampel jenuh) sebanyak 59 orang.

\subsection{Jenis Data dan Sumber Data}

Menurut Situmorang dan Lutfi (2014) cara memperolehnya data terbagi dua berdasar pada sumbernya yaitu: 1) Data primer (Primary Data) yaitu data yang dikumpulkan sendiri oleh perorangan/suatu organisasi secara langsung dari objek yang diteliti dan untuk kepentingan studi yang bersangkutan yang dapat berupa interview, kuesioner dan observasi. Data primer diperoleh dengan memberikan daftar pertanyaan (kuesioner) kepada karyawan PT. Asam Jawa Kab. Labuhanbatu. 2) Data sekunder (Secondary Data) yaitu data yang diperoleh atau dikumpulkan dan disatukan oleh studi-studi sebelumnya atau yang diterbitkan oleh berbagai instansi lain. Biasanya sumber tidak langsung berupa data dokumentasi dan arsiparsip resmi.

\subsection{Metode dan Teknik Pengumpulan Data}

Dalam penelitian ini, metode pengumpulan data yang digunakan adalah metode kuesioner, jenis kuesioner ini adalah kuesioner tertutup dengan skala likert. Teknik pengumpulan data dalam penelitian ini adalah kuesioner dan wawancara. Menurut Sugiyono (2010), teknik pengumpulan data meliputi:

a. Wawancara (Interview), digunakan sebagai teknik pengumpulan data apabila peneliti ingin melakukan studi pendahuluan untuk menemukan permasalah yang harus diteliti, dan juga apabila peneliti ingin mengetahui hal-hal dari responden yang lebih mendala dan jumlah respondennya sedikit atau kecil. Teknik pengumpulan data ini mendasarkan diri pada 
laporan tentang diri sendiri atau self report, atau setidak-tidaknya pada pengetahuan atau keyakinan pribadi.

b. Kuesioner, merupakan teknik pengumpulan data yang dilakukan dengan cara memberi seperangkat pertanyaan atau pernyataan tertulis kepada responden untuk dijawabnya. Kuesioner merupakan teknik pengumpulan data yang efisien bila peneliti tahu dengan pasti variable yang akan diukur dan tahu apa yang bisa diharapkan dari responden. Selain itu kuesioner juga cocok digunakan bila jumlah responden cukup besar dan tersebar di wilayah yang luas. Kuesioner dapat berupa pertanyaan/pernyataan tertutup atau terbuka, dapat diberikan kepada responden secara langsung atau dikirim melalui pos atau internet.

\section{HASIL PENELITIAN DAN PEMBAHASAN}

\subsection{Analisis Regresi Linear Berganda}

Metode analisis data yang digunakan dalam penelitian ini dengan mengumpulkan, mengolah, mengklasifikasikan dan menginterprestasikan data penelitian, sehingga diperoleh gambaran jelas mengenai objek yang diteliti dengan menggunakan Analisis Regresi Linier Berganda. Menurut Situmorang dan Lufti (2014) mengemukakan analisis regresi linear berganda ditujukan untuk menentukan hubungan linear antar beberapa variabel independen yaitu Kualitas Kerja $\left(\mathrm{X}_{1}\right)$, dan Lingkungan Kerja $\left(\mathrm{X}_{2}\right)$ dengan variabel dependen yaitu Kinerja Karyawan (Y).. Perhitungan persamaan regresi linear berganda adalah sebagai berikut :

$$
\mathbf{Y}=\mathbf{a}+\mathbf{b}_{1} \mathbf{X}_{1}+\mathbf{b}_{2} \mathbf{X}_{2}+\mathbf{e}
$$

\subsection{Uji Signifikan Secara Parsial (Uji-t)}

Untuk menguji apakah hipotesis yang diajukan diterima atau ditolak digunakan statistik $\mathrm{t}$ (uji t). Pengujian ini dilakukan untuk mengetahui seberapa besar pengaruh variabel bebas yaitu yaitu Kualitas Kerja $\left(\mathrm{X}_{1}\right)$ dan Lingkungan Kerja $\left(\mathrm{X}_{2}\right)$, secara parsial terhadap variabel terikat yaitu Kinerja Karyawan (Y). Uji parsial (uji t) dapat dilihat pada tabel berikut:

Tabel 4.1

Hasil Uji Parsial (Uji t) Coefficients $^{\mathrm{a}}$

\begin{tabular}{|c|c|c|c|c|c|c|}
\hline \multirow{2}{*}{\multicolumn{2}{|c|}{ Model }} & \multicolumn{2}{|c|}{$\begin{array}{c}\text { Unstandardized } \\
\text { Coefficients }\end{array}$} & \multirow{2}{*}{$\begin{array}{c}\text { Standardized } \\
\text { Coefficients } \\
\text { Beta }\end{array}$} & \multirow[t]{2}{*}{$\mathrm{T}$} & \multirow[t]{2}{*}{ Sig. } \\
\hline & & B & Std. Error & & & \\
\hline \multirow{3}{*}{1} & (Constant) & 5.593 & 1.319 & & 4.241 & .000 \\
\hline & Kualitas Kerja & .181 & .055 & .379 & 3.276 & .002 \\
\hline & Lingkungan Kerja & 291 & .096 & .349 & 3.021 & .004 \\
\hline
\end{tabular}

a. Dependent Variable: Kinerja Karyawan

Sumber : Hasil Penelitian (2020)

1) Untuk variabel Kualitas Kerja $\left(X_{1}\right)$, diperoleh nilai thitung yaitu 3,276 dengan taraf signifikansi 0,002. Jika dibandingkan dengan nilai $t_{\text {tabel }}$, maka $t_{\text {hitung }}(3,276)>t_{\text {tabel }}(1,672)$ dan taraf signifikasi $0,002<0,05$. Hal ini berarti bahwa secara parsial Kualitas Kerja berpengaruh signifikan terhadap Kinerja Karyawan pada PT. Asam Jawa. Dengan demikian berarti hipotesis dapat diterima.

2) Untuk variabel Lingkungan Kerja $\left(\mathrm{X}_{2}\right)$, diperoleh nilai $t_{\text {hitung }}$ yaitu 3,021 dan taraf signifikansi 0,004 . Jika dibandingkan dengan nilai $t_{\text {tabel }}$, maka $t_{\text {hitung }}(3,021)>t_{\text {tabel }}(1,672)$ dan taraf signifikansi $0,004<0,05$. Hal ini berarti bahwa secara parsial Lingkungan Kerja berpengaruh signifikan terhadap Kinerja Karyawan pada PT. Asam Jawa. Dengan demikian hipotesis diterima.

\subsection{Uji Signifikan Secara Serempak (Uji-F)}


Untuk menguji apakah hipotesis yang diajukan diterima atau ditolak digunakan uji F. Uji $\mathrm{F}$ bertujuan untuk mengetahui pengaruh secara serentak atau bersama-sama variabel bebas yaitu Kualitas Kerja $\left(\mathrm{X}_{1}\right)$, dan Lingkungan Kerja $\left(\mathrm{X}_{2}\right)$, terhadap variabel terikat Kinerja Karyawan (Y). Mencari nilai $F_{\text {hitung }}$ dengan menggunakan Tabel 4.2 ANOVA dari hasil pengolahan SPSS sebagai berikut:

Tabel 4.2

Hasil Uji Simultan (Uji F)

ANOVA ${ }^{a}$

\begin{tabular}{|l|l|r|r|r|r|r|}
\hline \multicolumn{2}{|l|}{ Model } & $\begin{array}{c}\text { Sum of } \\
\text { Squares }\end{array}$ & \multicolumn{1}{c|}{ Df } & $\begin{array}{c}\text { Mean } \\
\text { Square }\end{array}$ & F & Sig. \\
\hline \multirow{3}{*}{1} & Regression & 52.217 & 2 & 26.108 & 16.623 & $.000^{\mathrm{b}}$ \\
\cline { 2 - 8 } & Residual & 87.953 & 56 & 1.571 & & \\
\cline { 2 - 8 } & Total & 140.169 & 58 & & & \\
\hline
\end{tabular}

a. Dependent Variable: Kinerja Karyawan

b. Predictors: (Constant), Lingkungan Kerja, Kualitas Kerja

Sumber : Hasil Penelitian (2020)

Pada Tabel 4.2 dapat dilihat bahwa nilai $F_{\text {hitung }}$ adalah 16,623 dengan tingkat signifikansi 0,000. Berdasarkan hasil uji $\mathrm{F}$ data penelitian ini adalah signifikan, dapat dilihat dari nilai sig lebih kecil dari nilai alpha $(0,000<0,05)$. Bahwa variabel Kualitas Kerja dan Lingkungan Kerja secara bersama-sama (secara serempak) berpengaruh positif dan signifikan terhadap Kinerja Karyawan pada Karyawan PT. Asama Jawa.

\subsection{Koefisien Determinasi $\left(R^{2}\right)$}

Tabel 4.3

Model Summary ${ }^{b}$

\section{Koefisien Determinasi $\left(\mathbf{R}^{2}\right)$}

\begin{tabular}{|l|r|r|r|r|}
\hline Model & R & R Square & Adjusted R Square & Std. Error of the Estimate \\
\hline 1 & $.610^{\mathrm{a}}$ & .373 & .350 & 1.253 \\
\hline
\end{tabular}

a. Predictors: (Constant), Lingkungan Kerja, Kualitas Kerja

b. Dependent Variable: Kinerja Karyawan

Besarnya koefesien determinasi $\left(R^{2}\right)$ dapat dilihat pada kolom Ajusted $R$ Square sebesar 0,350 Nilai ini berarti bahwa Kinerja Karyawan mampu dijelaskan oleh Kualitas Kerja dan Lingkungan Kerja sebesar 35\%. Sedangkan sisanya sebesar $65 \%$ dipengaruhi variabel lain yang tidak diteliti dalam penelitian ini.

\subsection{Pembahasan Hasil Penelitian}

\section{Pengaruh Kualitas Kerja Terhadap Kierja Karyawan}

Berdasarkan uji t variabel Kualitas Kerja $\left(\mathrm{X}_{1}\right)$, diperoleh nilai thitung yaitu 3,276 dengan taraf signifikansi 0,002. Jika dibandingkan dengan nilai $t_{\text {tabel }}$, maka $t_{\text {hitung }}(3,276)>t_{\text {tabel }}(1,672)$ dan taraf signifikasi $0,002<0,05$. Hal ini berarti bahwa secara parsial Kualitas Kerja berpengaruh signifikan terhadap Kinerja Karyawan pada PT. Asam Jawa. Dengan demikian berarti hipotesis dapat diterima dan dengan demikian dapat disimpulkan variabel Kualitas Kerja $\left(\mathrm{X}_{1}\right)$ berpengaruh positif dan signifikan secara persial terhadap Kinerja Karyawan Karyawan PT. Asam Jawa.

Hasil penelitian ini mendukung teori sebelumnya yang dikemukakan oleh Siagian (2012) mengemukakan kualitas kerja merupakan upaya sistematis dalam kehidupan organisasional melalui cara dimana para karyawan diberi kesempatan untuk turut berperan menentukan cara mereka bekerja dan sumbangan yang mereka berikan kepada organisasi dalam rangka pencapaian tujuan dan berbagai sasarannya. 
Hal ini juga sesuai dengan penelitian sebelumnya salah satunya adalah Irawati (2015) dengan judul penelitian "Pengaruh Kualitas Kehidupan Kerja Terhadap Kinerja Karyawan Dinas Perindustrian Dan Perdagangan Kabupaten Sampang”. Penelitian ini dilakukan untuk mengetahui pengaruh kuaitas kehiduan kerja terhadap kinerja karyawan pada Dinas Perindustrian dan Perdagangan Kabupaten Sampang. Berdasarkan hasil F menunjukkan tingkat signifikan untuk uji $\mathrm{F}$ sebesar 0,034. karena nilai probabilitas $<0,05$ (sig $<5 \%$ ), berarti Pertumbuhan dan Pengembangan, Partisipasi, Lingkungan Kerja berpengaruh terhadap Kinerja Karyawan, sedangkan berdasarkan hasil uji t bahwa Variabel Lingkungan Kerja berpengaruh dominan karena diketahui tingkat signifikan sebesar 0.035, karena tingkat signifikan pada variabel ini lebih kecil dari 5\% (sig < 5\%). hal ini menujukkan bahwa lingkungan kerja harus mendapat perhatian penuh agar kinerja karyawan meningkat.

\section{Pengaruh Lingkungan Kerja Terhadap Kierja Karyawan}

Berdasarkan uji $t$ variabel Lingkungan Kerja $\left(\mathrm{X}_{2}\right)$, diperoleh nilai $\mathrm{t}_{\text {hitung }}$ yaitu 3,021 dan taraf signifikansi 0,004. Jika dibandingkan dengan nilai $t_{\text {tabel }}$, maka $t_{\text {hitung }}(3,021)>t_{\text {tabel }}(1,672)$ dan taraf signifikansi $0,004<0,05$. Hal ini berarti bahwa secara parsial Lingkungan Kerja berpengaruh signifikan terhadap Kinerja Karyawan pada PT. Asam Jawa. Demikian dapat disimpulkan variabel Lingkungan Kerja $\left(\mathrm{X}_{2}\right)$ berpengaruh positif dan signifikan secara persial terhadap Kinerja Karyawan PT. Asam Jawa.

Hasil penelitian ini mendukung teori sebelumnya yang dikemukakan oleh Sedarmayanti (2012) definisi lingkungan kerja sebagai berikut: Lingkungan kerja adalah keseluruhan alat perkakas dan bahan yang dihadapi, lingkungan sekitarnya di mana seseorang pekerja, metode kerjanya, serta pengaturan kerjanya baik sebagai perseorangan maupun sebagai kelompok.

Hal ini juga sesuai dengan penelitian sebelumnya salah satunya adalah penelitian yang dilakukan Pratama (2015) Dengan Judul "Pengaruh Motivasi Kerja Dan Lingkungan Kerja Terhadap Kinerja Karyawan Pada Perusahaan Daerah Air Minum (PDAM) Kabupaten Sleman. Penelitian ini bertujuan untuk mengetahui: (1) Pengaruh variabel motivasi kerja terhadap kinerja karyawan PDAM Kabupaten Sleman (2) Pengaruh variabel lingkungan kerja terhadap kinerja karyawan PDAM Kabupaten Sleman (3) Pengaruh variabel motivasi kerja dan lingkungan kerja terhadap kinerja karyawan PDAM Kabupaten Sleman. Hasil penelitian pada taraf signifikansi 5\% menemukan bahwa:(1) Pengaruh motivasi kerja terhadap kinerja karyawan PDAM Kabupaten Slemansebesar $(\beta) 0,344(\mathrm{p}<0.05 ; \mathrm{p}=0,000)$. Kontribusi motivasi kerja untuk menjelaskan kinerja karyawan sebesar $\left(R^{2}\right) 0,080$. (2) Pengaruh lingkungan kerja terhadap kinerja karyawan sebesar $(\beta) 0,291(\mathrm{p}<0.01 ; \mathrm{p}=0,000)$. Kontribusi lingkungan kerja untuk menjelaskan kinerja karyawan PDAM Kabupaten Sleman sebesar $\left(R^{2}\right) 0,067$. (3) Motivasi kerja $(\beta) 0,302(p<0.05 ; p=0,000)$ dan lingkungan kerja $(\beta) 0,247(p<0.05 ; p=0,000)$ secara simultan berpengaruh positif terhadap kinerja karyawan PDAM Kabupaten Sleman. Kontribusi motivasi kerja dan lingkungan kerja untuk menjelaskan kinerja karyawan PDAM Kabupaten Sleman sebesar $\left(\mathbf{R}^{2}\right)$ 0,127.

\section{Pengaruh Insentif dan Motivasi Kerja Terhadap Kierja Karyawan}

Berdasarkan hasil penelitian maka diperoleh nilai $F_{\text {hitung }}$ sebesar 16,623 sedangkan nilai $F_{\text {tabel }}$ pada tingkat kepercayaan $95 \%(\alpha=0,05)$ adalah 3,16 . Ini berarti $F_{\text {hitung }} 16,623>F_{\text {tabel }} 3,16$ yaitu Ha diterima dan Ho ditolak. Untuk tingkat signifikansinya $0,000<0,05$, menunjukkan bahwa variabel Kualitas Kerja dan Lingkungan Kerja secara bersama-sama (secara serempak) berpengaruh positif dan signifikan terhadap Kinerja Karyawan PT. Asam Jawa.

\section{KESIMPULAN DAN SARAN}




\subsection{Kesimpulan}

Kesimpulan yang dirumuskan penulis dalam penelitian dengan judul "Pengaruh Insentif Dan Motivasi Kerja Terhadap Kinerja Karyawan Pada PT. PLN (Persero) Cabang Rantauprapat" adalah:

1. Pengujian secara parsial Kualitas Kerja $\left(X_{1}\right)$, berpengaruh signifikan terhadap Kinerja Karyawan pada PT. Asam Jawa dengan nilai $t_{\text {tabel}}$, maka $t_{\text {hitung }}(3,276)>t_{\text {tabel }}(1,672)$ dan taraf signifikasi $0,002<0,05$ yang berarti Ho ditolak dan Ha diterima.

2. Pengujian secara parsial Lingkungan Kerja $\left(X_{2}\right)$, berpengaruh signifikan terhadap Kinerja Karyawan pada PT. Asam Jawa dengan nilai thitung $(3,021)>t_{\text {tabel }}(1,672)$ dan taraf signifikansi $0,004<0,05$ yang berarti Ho ditolak dan Ha diterima.

3. Pengujian secara simultan Kualitas Kerja dan Lingkungan Kerja secara bersama-sama (secara serempak) berpengaruh positif dan signifikan terhadap Kinerja Karyawan PT. Asam Jawa dengan nilai $F_{\text {hitung }} 16,623>F_{\text {tabel }}$ 3,16 yaitu Ho ditolak dan Ha diterima.

\section{DAFTAR PUSTAKA}

Alex. S. Nitisemito, 2011, Manajemen Personalia. Edisi Revisi, Penerbit Ghalia Indonesia. Hasibuan Melayu, 2012. Manajemen Sumber Daya Manusia. Jakarta. Bumi Aksara.

Irawati. S. Anugrahini 2015 Pengaruh Kualitas Kehidupan Kerja Terhadap Kinerja Karyawan

Dinas Perindustrian Dan Perdagangan Kabupaten Sampang. Jurnal Neo-bis. Volume 9, No. 2, Des 2015

Mangkunegara, AA. 2011. Evaluasi Kinerja SDM. Refika Aditema. Bandung.

Pratama, Yofanda Budi. 2015. Pengaruh Motivasi Kerja Dan Lingkungan Kerja Terhadap Kinerja Karyawan Pada Perusahaan Daerah Air Minum (PDAM) Kabupaten Sleman.

Siagian, Sondang P. 2012, Manajemen Sumber Daya Manusia, Bumi Aksara, Jakarta.

Sedarmayanti. 2012. Manajemen Sumber Daya Manusia, Reformasi Birokrasi dan Manajemen Karyawan Negeri Sipil (cetakan kelima). Bandung : Refika Aditama

Situmorang dan Lufti, 2014. Analisis Data untuk Riset Manajemen dan Bisnis, USU Press, Medan.

Sugiyono, 2010. Metode Penelitian Kuantitatif kualitatif dan $R \& D$, Alfabeta, Bandung. 